\title{
History and Uses of the Ionospheric, Thermospheric, and Atmospheric Data Base
}

\author{
Dieter BILITZA* \\ Institute of Space and Astronautical Science, 3-1-1 Yoshinodai, Sagamihara, Kanagawa 229, Japan
}

(Received August 27, 1990; Revised September 5, 1990)

\begin{abstract}
A short chronicle of data collection in the ionosphere, thermosphere and atmosphere is given, highlighting the different measurement techniques and their effect on the overall data volume. Several data sources and their uses are discussed in greater detail, including the data obtained by the worldwide ionosonde network, by the incoherent scatter radars, by the Alouette and ISIS topside sounders, and by the Atmosphere Explorer satellite. The need for continuous monitoring from ground and space is stressed, as well as the need for preservation of older data records and their full scientific exploitation.
\end{abstract}

\section{History}

In 1647 the French scientist and philosopher Pascal carried a mercury barometer to the top of the Puy de Dome in France. His pressure measurements confirmed the decrease of atmospheric pressure with increasing height, as Torricelli, a student of Galileo, had postulated a few years earlier. This can be considered the starting point of atmospheric data collection. Over the next centuries mountain climbers and later also balloonist accumulated more information about the rates at which atmospheric pressure and temperature decrease with altitude, thereby allowing first (rather low) estimates of the upper boundary of Earth's atmosphere. By the end of the 18th century instrument-carrying balloons revealed that at very high altitudes the temperature begins to increase with increasing altitude, prompting the distinction between the turbulent lower troposphere and the stratosphere higher up.

Coordinated data collection begun in earnest in 1892 during what was called the First International Polar Year. Researchers all over the world carried out measurements to investigate, among other subjects, meteorology, the aurora, and geomagnetism. At the time of the Second International Polar Year in 1933 a new instrument, the ionosonde, rapidly increased the data pool available for ionospheric research. Marconi's historic transmission of radio signals across the Atlantic Ocean in 1901 had led the way to the discovery of an ionized region in the upper atmosphere, the ionosphere, and to the first dedicated radio experiments in 1924. Starting in the mid-twenties several groups around the globe began to apply radio echo sounding to explore the structure and morphology of the ionosphere and thermosphere.

On September 8, 1944 the first German V-2 rocket carried its deadly load across the Channel and detonated near London. An event with far reaching consequences for both U.S.A.

*On leave from NASA, Goddard Space Flight Center, Code 933, NSSDC, SAR, Greenbelt, MD 20771, 


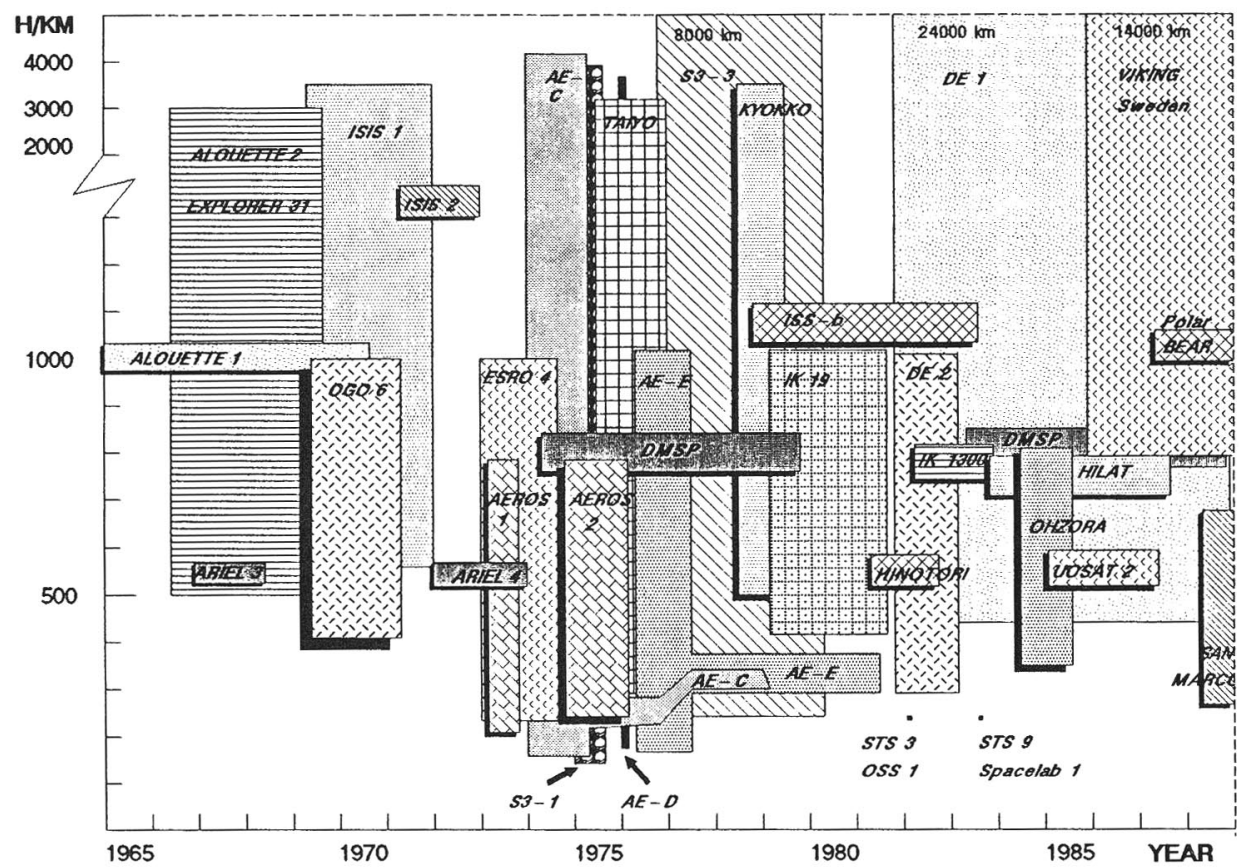

Fig. 1. Altitude/time chart of satellites measuring in situ in the ionosphere and thermosphere (BILITZA, 1989). Note: Alouette 1, 2, ISIS 1, 2, IK19, and ISS-b carried topside sounders measuring the electron density down to the F peak; ISIS topside ionograms were recorded up to 1989.

technology and warfare. After the war the potential use of these rockets for atmospheric and ionospheric research was recognized and the V-2 Upper Atmosphere Research Panel was formed in the U.S. in January 1946. An excellent account of the impact of V-2 rocket on atmospheric research was given by CURTIS (1979). By 1952 Aerobee rockets carrying scientific payloads to altitudes of up to $250 \mathrm{~km}$ revealed a multitude of new and unexpected phenomena in the upper atmosphere. Soon several other countries launched rocket programs to study the ionosphere and thermosphere with in-situ experiments. During the Third International Polar Year-more appropriately renamed as the first International Geophysical Year (IGY)-from 1957 to 1958 close to 400 rockets were launched mostly from high northern latitudes.

A new era of geospace exploration began in 1957, when Sputnik, the first artificial satellite, sent its signals back to Earth. Satellite instruments were able to measure the characteristic parameters over the whole latitudinal and altitudinal extent of the atmosphere and ionosphere. Between 1960 and 1965 a series of high-drag satellites was launched, whose orbital decay showed that the extent of the atmosphere had been severely underestimated in earlier studies. The average densities deduced from the drag data allowed also a first assessment of solar activity effects. In 1962 the US-Canadian Alouette 1 satellite was put into orbit, followed later by Alouette 2, ISIS 1, and 2 (see program summary by JACKSON, 1986a). They all carried topside sounders, an instrument similar to the ground-based 
ionosonde. Looking down from above these sounders monitored the structure of the electron density above the $F$ peak.

The early satellites revealed the enormous complexity of Earth's atmosphere and its many characteristic regions. A better understanding of the important processes could only be obtained by measuring all the dominant parameters simultaneously. Thus, beginning in 1965 a series of Orbiting Geophysical Observatories (OGO) was launched carrying a wide range of plasma, optical and radio experiments (see program summary by JACKSON and VETTE, 1975). Recognizing the orbital limitations in time and space of a single satellite, NASA designed the armada of Atmosphere Explorer (AE) satellites (HANSON, 1973) and operated them in complementary orbits from 1974 to 1981 . While AE-C, -D, and -E provided the data base for the study of coupling processes between the thermosphere and ionosphere, the Dynamics Explorer 1 and 2 satellites (HOFMANN, 1981; SPENCER and NAGY, 1982), launched in 1981, enabled scientists to look at the coupling between those two regions and the magnetosphere. The satellites most important for upper atmospheric research are summarized in Fig. 1 showing their altitude coverage and the most data-intensive part of their mission lifetime.

Ground-based monitoring of atmospheric and ionospheric temperatures and densities improved significantly over the past decades. In 1958 the first incoherent scatter radar measurements were carried out by BOWLES (1958) as proposed by GORDON (1958). With this technique it became possible to observe simultaneously a large number of characteristic parameters in the altitude range from 150 to $800 \mathrm{~km}$. The power and antenna requirements, however, make this a rather expensive technique. Thus only a small number of stations are operated on a routine basis, worldwide; most radar facilities are described in a special issue of Radio Science (Vol. 9, No. 2, 1974).

\section{Data Base and Uses}

The ionospheric, atmospheric, and thermospheric data base as a whole has grown enormously in this century. Step by step the introduction of new measurement techniques from balloon instruments to ionosondes to rocket and satellite experiments to incoherent scatter radars has extended our data pool and our knowledge base. The ever increasing temporal and spatial resolution of these data has enabled scientists to unravel in ever greater detail the processes that govern the distribution of energy and particles in near-earth space. Theoretical and empirical modelers have made ample use of this large data base steadily enhancing our ability to understand past variation patterns and to predict future trends.

Keeping within the scope of this article, we will focus on a few instrument-specific data sets, which constitute important sections of the total data base: (1) ionosonde data, (2) Alouette, ISIS topside sounder data, (3) AE data, and (4) incoherent scatter data. A comprehensive guide to the worldwide ionospheric data base was published by BILITZA (1989).

\subsection{Ionosonde data}

Since the forties the more or less continuous operation of the worldwide network of ionosondes, has accumulated the longest ionospheric data record monitoring the $E$ and $F$ layer peak parameters over more than half a century. Commercial radio that followed soon after Marconi's experiment has profited greatly from this large data base. The ionosonde measurements helped to specify the regular variation patterns of the reflecting layers during 
the diurnal, seasonal and solar cycles and thus allowed radio operators to chose the most favorable transmission frequencies and paths. During World War II the military soon recognized the importance of ionospheric predictions for uninterrupted communication links between troops and each side undertook considerable efforts to increase the forecast accuracy. After the war the Consultative Committee for International Communications (CCIR) and the International Union of Radio Science (URSI) internationalized these efforts and promoted further improvements of the global maps of ionospheric characteristics (CCIR, 1967). The most recent update was presented by RUSH et al. (1989).

Many of the ionospheric anomalies and irregularities were first discovered in ionosonde records. The equator anomaly, spread- $F$ (named after the ionogram signature), and sporadic- $E$ are just a few examples. Ionosondes are the prime instruments for specifying the ionospheric response to changing solar-terrestrial conditions as manifested in the ionosonde-based IF and IG "solar" activity indices (LIU et al., 1983), and as documented by the successful SUNDIAL program (see Annales Geophysicae, Vol. 6, No. 1, 1988, and Vol. 8, No. 6, 1990).

Figure 2 shows the development of the worldwide ionosonde network over the last decades. Clearly recognizable is the positive impact of the IGY and the IQSY (International Quiet Sun Year 1964/65) on the total number of stations. Unfortunately, several ionosondes have terminated operations in recent years. The development of automatically recording ionosondes (digisondes) employing micro-processors and PCs (REINISCH, 1986) has generated new interest in the venerable old-timer of ionosphere monitoring. Ionosonde data are archived at the World Data Centers (WDCs) as described in the catalog by CONKRIGHT et al. (1984). Establishment of the WDCs during the IGY was the starting point of an international data base accessible to users all over the world. The individual WDCs store and distribute discipline-oriented data sets according to their regional responsibilities (ICSU, 1979).

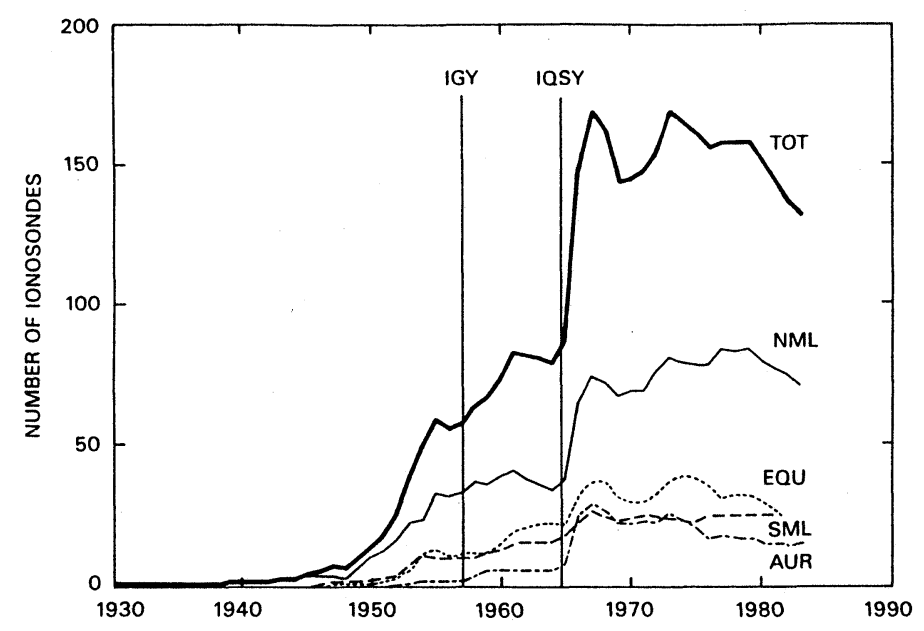

Fig. 2. Number of ionosondes operational since 1930: TOT $=$ total number, NML $=$ number of ionosondes at northern midlatitudes, $\mathrm{EQU}=$ at equatorial latitudes, $\mathrm{SML}=$ at southern midlatitudes, $\mathrm{AUR}=$ at auroral latitudes; IGY = International Geophysical Year 1957/58, IQSY = International Quiet Sun Year $1964 / 65$. 


\subsection{Alouette, ISIS topside sounder data}

The US-Canadian Alouette and ISIS missions are examples of a well planned and executed satellite program as summarized by JACKSON (1986a) and documented in a special issue of the Proceedings of IEEE edited by SCHMERLING and LANGUILLE (1969). It was also the first satellite program to make extensive and well documented contributions of data to the World Data Centers. The topside sounder instrument was at the heart of these missions and provided a wealth of information about the ionosphere above the $F$ peak, a region not accessible with ground-based ionosondes. Thus it was found that the equator anomaly extends high into the topside ionosphere. At high latitudes the characteristic electron density features, like trough and cusp, could be studied systematically for the first time. Summaries of the most important results can be found in the compilations by SCHMERLING and LANGUILLE (1969) and by JACKSON (1988). BENT and LLEWELLYN (1973) used Alouette data for their empirical model, that is still applied by most space agencies to correct for the ionospheric effects in satellite orbit determinations (e.g. BILITZA et al., 1988). The past and present of topside sounding was reviewed by JACKSON et al. (1980).

After NASA terminated its support of the ISIS sounders in October 1979, the Canadian team continued data acquisition till March 1984, and after that the Japanese Radio Research Laboratory operated the sounders till January 1990. The National Space Science Data Center and World Data Center A for Rockets and Satellites (NSSDC/WDC-A-R\&S) in Greenbelt, Maryland archives about 100 data sets from the Alouette-ISIS missions including about $4,000,000$ ionograms (JACKSON, 1986b), of which so far only about $2.5 \%$ have been reduced to electron density profiles. How many treasures may be hidden in the as yet not analyzed part of this huge data base? How much bettter would be our forecast, if the whole AlouetteISIS data base would be considered?

\subsection{Atmosphere Explorer (AE) data}

The fleet of AE-C, D and E satellites collected data from December 1973, when AE-C was launched, until June 1981, when AE-E re-entered. Up to 17 instruments per satellite (see Table 1) provided a detailed picture of photochemical and energy-transport processes in the coupled system of ionosphere and thermosphere. A good summary of the mission concept and objectives, the payloads, the data handling system, and the scientific results is given in the book by BURGESS et al. (1987).

For the first time a centralized data system was used with an on-line repository of data that were readily accessible to users through their remote terminals. The central Sigma 9 computer, a strong team work, and data sharing from early on were important features of the $\mathrm{AE}$ program. In many ways the AE data handling system was the successful pilot for most of NASA's later Earth and planetary missions. Processed data from several instruments were combined in the so-called Unified Abstract (UA) files with 15 seconds time resolution. NSSDC/WDC-A-R\&S now archives and distributes these UA files together with orbitattitude files on altogether 134 tapes. Raw data and data with higher time resolution, however, are generally held by the principal investigators and there is concern that some of these valuable data sets may get lost, if not also stored at a central facility. It is hoped that new high-volume storage media, like optical disks, will allow the data centers to expand their level of archiving in the near future. 
Table 1. Atmosphere explorer instruments.

\begin{tabular}{|c|c|c|c|c|}
\hline Investigator & Organization & Instrument & Flights & Parameters \\
\hline H. Hinteregger & AFGL & Solar EUV Spectrometer (EUVS) & $\mathrm{C}, \mathrm{D}$, and $\mathrm{E}$ & 140 to $1850 \mathrm{~A}$ \\
\hline D. Health & GSFC & $\begin{array}{l}\text { Solar EUV Filter Photometer } \\
\text { (ESUM) }\end{array}$ & $\mathrm{C}, \mathrm{D}$, and $\mathrm{E}$ & 40 to $1300 \mathrm{~A}$ \\
\hline $\begin{array}{l}\text { C. Barth and } \\
\text { I. Stewart }\end{array}$ & U. of Col. & UV Nitric Oxide (UVNO) & $\mathrm{C}$ and $\mathrm{D}$ & 2150 to $2190 \mathrm{~A}$ \\
\hline P. Hays & U. of Mich. & Airglow Photometer (VAE) & $\mathrm{C}, \mathrm{D}$, and $\mathrm{E}$ & $\begin{array}{l}6300,5577,4278, \\
3371,5200,7319 \\
\text { to } 7330 \mathrm{~A}\end{array}$ \\
\hline A. Nier & U. of Minn. & $\begin{array}{l}\text { Open-Source Neutral Mass } \\
\text { Spectrometer (OSS) }\end{array}$ & $\mathrm{C}, \mathrm{D}$, and $\mathrm{E}$ & 1 to $46 \mathrm{amu}$ \\
\hline $\begin{array}{l}\text { A. Hedin } \\
\text { (D. Pelz) }\end{array}$ & GSFC & $\begin{array}{l}\text { Closed-Source Neutral Mass } \\
\text { Spectrometer (NACE) }\end{array}$ & $\mathrm{C}, \mathrm{D}$, and $\mathrm{E}$ & 1 to 46 amu \\
\hline N. Spencer & GSFC & Neutral Atm. Temp. Exp. (NATE) & $\mathrm{C}, \mathrm{D}$, and $\mathrm{E}$ & $\mathrm{T}_{\mathrm{g}}, \mathrm{N}_{2}, \mathrm{~V}_{\mathrm{w}}$ \\
\hline K. Champion & AFCRL & Atm. Density Accel. (MESA) & $\mathrm{C}, \mathrm{D}$, and $\mathrm{E}$ & Neutral density \\
\hline W. Hanson & $\begin{array}{l}\text { U. of Tex. } \\
\text { Dallas }\end{array}$ & Planar Ion Trap (RPA) & $\mathrm{C}, \mathrm{D}$, and $\mathrm{E}$ & $\begin{array}{l}T_{i}, N_{i}, M_{i} \text {, drift } \\
\text { velocity }\end{array}$ \\
\hline L. Brace & GSFC & Cylindrical Electrostatic Probe & $\mathrm{C}, \mathrm{D}$, and $\mathrm{E}$ & $\mathrm{T}_{\mathrm{e}}, \mathrm{N}_{\mathrm{e}}, \mathrm{N}_{\mathrm{i}}, \mathrm{M}_{\mathrm{i}}$ \\
\hline J. Hoffman & $\begin{array}{l}\text { U. of Tex. } \\
\text { Dallas }\end{array}$ & $\begin{array}{l}\text { Magnetic Ion Mass Spectrometer } \\
\text { (MIMS) }\end{array}$ & $\mathrm{C}$ and $\mathrm{D}$ & 1 to $64 \mathrm{amu}$ \\
\hline H. Brinton & GSFC & $\begin{array}{l}\text { Positive Ion Mass Spectrometer } \\
\text { (BIMS) }\end{array}$ & $\mathrm{C}$ and $\mathrm{E}$ & 0.5 to $72 \mathrm{amu}$ \\
\hline R. Hoffman & GSFC & Low-Energy Electron Exp. (LEE) & $\mathrm{C}$ and $\mathrm{D}$ & 0.2 to $25 \mathrm{keV}$ \\
\hline J. Doering & J. H. Univ. & Photoelectron Spectrometer (PES) & $\mathrm{C}, \mathrm{D}$, and $\mathrm{E}$ & $\begin{array}{l}\text { Photoelectron } \\
\text { spectra }\end{array}$ \\
\hline $\begin{array}{l}\text { C. Rice and } \\
\text { S. LaValle }\end{array}$ & $\begin{array}{l}\text { Aerospace } \\
\text { Corp. }\end{array}$ & Capacitance Manometer & $\mathrm{C}, \mathrm{D}$, and $\mathrm{E}$ & Pressure \\
\hline $\begin{array}{l}\text { C. Rice } \\
\text { (V. Carter) }\end{array}$ & $\begin{array}{l}\text { Aerospace } \\
\text { Corp. }\end{array}$ & Cold Cathode Ion Gage Range & $\mathrm{C}, \mathrm{D}$, and $\mathrm{E}$ & Pressure \\
\hline E. Young & GSFC & Temperature Alarm & $\mathrm{C}, \mathrm{D}$, and $\mathrm{E}$ & $\begin{array}{l}\text { Aerodynamic } \\
\text { heating }\end{array}$ \\
\hline
\end{tabular}

$\mathrm{T}_{\mathrm{e}}$ - electron temperature

$\mathrm{T}_{\mathrm{i}}$ - ion temperature

$\mathrm{T}_{\mathrm{g}}$ - gas temperature

$$
\begin{aligned}
& \mathrm{N}_{\mathrm{e}} \text { - electron density } \\
& \mathrm{N}_{\mathrm{i}} \text { - ion density } \\
& \mathrm{M}_{\mathrm{i}} \text { - ion mass }
\end{aligned}
$$

\subsection{Incoherent scatter data}

Since the initial experiments in 1958 about ten radars, all at northern latitudes, have provide incoherent scatter data for scientific purposes. Only the facilities in Jicamarca (Peru), Arecibo (puerto Rico), Millstone Hill (Massachusetts) and St. Santin (France) have been operated on a routine bases since the mid-sixties. Since the early eighties three more stations operate at Kyoto (Japan), Tromso (Norway), and Soundrestrom (Greenland). Excellent reviews of the theory and practice of this technique were published by EVANS $(1969,1975)$.

The high-latitude radars have been powerful tools in investigations of the coupling mechanisms between the ionosphere, thermosphere and magnetosphere. At the magnetic equator, data taken by the Jicamarca radar in Peru have provided altitude-time images of the turbulent ionosphere showing the rise and fall of plasma layers and localized depletions (bubbles). Recent results from the different radars are discussed in a special issue of Advances in Space Research (GANGULY, 1989). Radar data have been also key elements of coordinated 
measurement programs and international initiatives, like CEDAR (SICA et al., 1988), WITS (LIU, 1989) and the earlier mentioned SUNDIAL project. Their very essential contributions to empirical modeling were reviewed by OLIVER et al. (1988) and RAWER and BILITZA (1985). In 1985 a central data facility was established at the National Center for Atmospheric Research in Boulder (Colorado). NCAR archives raw and reduced data from the different stations and gives access to these data. An inventory catalog is published at least once per year.

\section{Summary and Outlook}

Geophysical data bases serve two major purposes, one is to understand the underlying forces and chemistry with the goal of realistic theoretical simulations, and the other is to deduce the characteristic variation patterns with the goal of reliable empirical models. In either case the most obvious investment revenue for the tax-paying public, is an improved forcast capability for the near-earth environment. A wide range of applications depend critically on such forecasts including tele-communications, Earth observation from space, navigation, search and rescue and many more. International working groups under the auspices of the Committee on Space Research (COSPAR) have efficiently coordinated the worldwide modeling efforts resulting in the International Reference Ionosphere (IRI) (RAWER and BRADLEY, 1990; RAWER and Piggott, 1990) and in the COSPAR International Reference Atmosphere (CIRA) (REES, 1988; RYCROFT et al., 1990). The steadily improved editions of these models issued over the years, document the positive impact of the increasing data base. It is of paramount importance that this process continues.

Since 1985, when first reported by FARMAN et al. (1985), the substantial springtime reduction in Antartic ozone, the ozone hole (STOLARSKI, 1988), has focused world attention on the fragility of the thin stratospheric layer. We should learn our lessons from this warning shot across the bow of spaceship Earth. Continuous monitoring of atmospheric and ionospheric parameters from ground and space is a necessity for the timely discovery of changes in Earth's atmosphere and for the assessment of their consequences for life on our planet. This we owe also to future generations, whose challenges may be far more severe and existential than our present concerns about the antartic ozone hole and the greenhouse effect.

Advances in data storage, distribution and management are necessary to cope with the increased data rates and volume of the future (CODMAC, 1982, 1986, 1988; CARPER et al., 1987). Applied to the already existing data base, such new technologies could help to fully exploit the data treasures buried on tapes of raw data and on analog media, like microfilms and stripcharts. A "Mission for Data Analysis" was one of the recommendations of the recent Solar-Terrestrial Science Strategy Workshop (BANKS et al., 1989): "Intergrating old data with new theories, it may be possible to confirm new concepts and relationships." A good example is the work by LABITZKE and VAN LOON $(1988,1989)$, who found a correlation between atmospheric parameters and the 11-year solar cycle if they grouped the data according to equatorial wind direction.

It seems fitting to close with a quote from the book 2001 of the great visionary* Arthur C. Clarke: "Since the first satellites had orbited, almost fifty years earlier, trillions and

*A. C. Clarke was one of the advocates for the peaceful use of the German V-2 rockets. Already in 1945 he suggested the V-2 as vehicles for ionospheric research and even mentioned the use of this rockets as a first stage for launching artificial satellites. 
quadrillions of pulses of information had been pouring down from space, to be stored against the day when they might contribute to the advance of knowledge. Only a minute fraction of all this raw material would ever be processed; but there was no way of telling what observations some scientist might wish to consult, ten or fifty, or hundred years from now. So everything had to be kept on file, stacked in endless air-conditioned galleries, triplicated at the three centers against the possibility of accidental loss. It was part of the real treasure of mankind, more valuable than all the gold locked uselessly away in bank vaults."

\section{REFERENCES}

Banks, P., W. T. Roberts, and J. Kropp (eds.), Solar-Terrestrial Science Strategy Workshop, National Aeronautics and Space Administration, Conference Publication 3048, Washington, D.C., 1989.

Bent, R. B. and S. K. Llewellyn, Documentation and Description of the Bent Ionospheric Model, Air Force Geophysics Laboratory, Report AFGL-TR-73-0657, Hanscom AFB, Massachusetts, 1973.

BILITZA, D., The Worldwide Ionospheric Data Base, National Space Science Data Center, NSSDC 89-03, Greenbelt, Maryland, 1989.

Bilitza, D., K. Rawer, and S. Pallaschke, Study of ionospheric models for satellite orbit determination, Radio, Sci., 23, 223-232, 1988.

Bowles, K. L., Observations of vertical incidence scatter from the ionosphere at $41 \mathrm{Mc} / \mathrm{sec}$, Phys. Rev. Lett., 1, 454, 1958.

Burgess, E., D. TORR, and AE INVESTIGATORS, Into the Thermosphere-The Atmosphere Explorers, National Aeronautics and Space Administration, SP-490, Washington, D.C., 1987.

Carper, R., J. Dalton, M. Healey, L. Kempster, J. Martin, F. McCaleb, S. Sobieski, and J. Sos, Mass storage systems for data transport in the early Space Station era 1992-1998, National Astronautical and Space Administration, NASA Technical Memorandum 87826, Wahington, D.C., 1987.

CCIR, Atlas of ionospheric Characteristics, Comite Consultatif International des Radiocommunications, Report 340-4 (and later supplements) International Telecommunications Union, Geneva, 1967.

CODMAC, Committee on Data Management and Computation, Vol. 1: Issues and Recommendations, National Academy Press, Washington, D.C., 1982.

CODMAC, Committee on Data Management and Computation, Issues and Recommendations associated with distributed Computation and Data Management Systems for the Space Sciences, National Academy Press, Washington, D.C., 1986.

CODMAC, Committee on Data Management and Computation, Selected Issues in Space Science Data Management and Computation, National Academy Press, Washington, D.C., 1988.

Conkright, R., M. Ertle, M. Hapgood, A. Feldstein, and N. Matuura, Combined Catalog of Ionosphere Vertical Soundings Data, World Data Center A for Solar-Terrestrial Physics, Report UAG-91, Boulder, Colorado, 1984.

Curtis, S. A., The use of the German V-2 in US for upper atmosphere research, Journal of the British Interplanetary Society, 32, 443-448, 1979.

Evans, J. V., Theory and Practice of ionosphere study by Thompson scatter radar, Proc IEEE, 57(4), 496, 1969.

Evans, J. V., High-power radar studies of the ionosphere, Proc. IEEE, 63(12), 1636, 1975.

Farman, J. C., B. G. Gardiner, and J. D. Shanklin, Large losses of total ozone in Antaritica reveal seasonal $\mathrm{ClO}_{x} / \mathrm{NO}_{x}$ interaction, Nature, 315, 207-210, 1985.

Ganguly, S. (ed.), Ionospheric Incoherent Scatter Results, Adv. Space Res., 9, \#5, 1989.

GORDON, W. E., Incoherent scattering of radio waves by free electrons with applications to space exploration by radar, Proc. IRE, 46, 1824, 1958.

Hanson, W. B. (ed.), Special issue on Atmosphere Explorer mission and experiments, Radio Sci., 8, 261$405,1973$.

Hofmann, R. A. (ed.), Dynamics Explorer, Space Science Instrumentation, 5, No. 4, 1981.

ICSU, Guide to international data exchange through the World Data Centers, International Committe of Scientific Unions, Panel on World Data Centers, Washington, D.C., 1979.

JACKSON, J. E., Alouette ISIS Program Summary, National Space Science Data Center, NSSDC 86-09, Greenbelt, Maryland, 1986a. 
JACKSON, J. E., Calibration and identification of Alouette and ISIS topside ionogram, National Space Science Data Center, NSSDC 86-06, Greenbelt, Maryland, 1986b.

JACKson, J. E., Results from Alouette 1, Explorer 20, Alouette 2 and Explorer 31, National Space Science Data Center, NSSDC 88-10, Greenbelt, Maryland, 1988.

JACKSON, J. E. and J. I. VetTe, OGO Program Summary, National Astronautical and Space Administration, NASA SP-7601, Washington, D.C., 1975. (and Supplement, 1978).

JACKson, J. E., E. R. SChmerling, and J. H. Whitteker, Mini-review of topside sounding, IEEE Transact. Antennas Propagation, AP-28, 284, 1980.

LABITZKE, K. and H. VAN Loon, Associations between the 11-year solar cycle, the QBO, and the atmosphere, J. Atmos. Terr. Phys., 50, 197-206, 1988.

LABITZKe, K. and H. van LoON, The 11-year solar cycle in the stratosphere in the northern summer, Annales Geophysicae, 7, 595-598, 1989.

LiU, C. H. (ed.), World Ionosphere/Thermosphere Study, WITS Handbook, Vol. 1 and 2, Scientific Committee on Solar-Terrestrial Physics, University of Illinois, Urbana, 1989.

LiU, R. Y., P. A. SMITH, and J. W. KING, A new solar index which leads to improved $f_{0} F 2$ predictions using the CCIR atlas, Telecomm. J., 50, 408, 1983.

Oliver, W. L., D. Alcayde, and P. BAuer, Incoherent Scatter radar contributions (to CIRA), Adv. Space Res., 8, \#5/6, 119-148, 1988.

RAWER, K. and D. BILITZA, The interest of information obtained by incoherent scatter technique (for IRI), Adv. Space Res., 5, \#10, 9-14, 1985.

Rawer, K. and P. A. Bradley (eds.), Ionospheric Informatics and Empirical Modeling, Adv. Space Res., 10, \#8, 1990.

Rawer, K. and W. R. Piggott (eds.), Development of IRI-90, Adv. Space Res., 1990 (in press).

ReEs. D. (ed.), CIRA 1986, Part I: Thermosphere Model, Adv. Space Res., 8, \#5/6, 1988.

ReINisch, B. W., New techniques in ionospheric sounding, Radio Sci., 21, 331-341, 1986.

Rush, C., M. Fox, D. Bilitza, K. Davies, L. Mcnamara, F. Stewart, and M. Pokempner, Ionospheric Mapping: An Update of $f_{\mathrm{o}} F 2$ Coefficients, Telecomm. J., 56, 179, 1989.

Rycroft, M. J., G. M. Keating, and D. ReEs (eds.), Upper Atmosphere Models and Research, Adv. Space Res., 10, \#6, 1990.

Schmerling, E. R. and R. C. Languille (eds.), Special Issue on topside sounding and the ionosphere, Proc. IEEE, 57, No. 6, 859-1179, 1969.

Sica, R. J., A. D. Richmond, B. A. Emery, S. Chakrabarti, and V. B. Wickwar, The first Cedar data base report, National Center for Atmospheric Research, Technical Note 308+STR, Boulder, Colorado, 1988.

Spencer, N. W. and A. F. NAgy (eds.), DE first results, Geophys. Res. Lett., 9, No. 9, 1982.

Stolarski, R. S., The Antarctic ozone hole, Scientific American 258, 1, 30-36, 1988. 